\title{
INFLUENCE OF INDIGENOUS LANGUAGE AND AUTHORITY FIGURES IN BROADCAST OF COVID-19 PANDEMIC MESSAGES AMONG RURAL DWELLERS IN SOUTH EAST NIGERIA
}

\author{
Chinelo Edith Ude-Akpeh \\ Department of TV Journalism \\ NTATelevision College, Jos \\ neloudeakpeh@yahoo.com \\ 08066144316 \\ Tony Onyima \\ Department of MassCommunication \\ Chukwuemeka Odumegwu Ojukwu University \\ Igbariam \\ ifeidemili@gmail.com \\ 08036729418
Alpha Chukwuemeka Ginikachukwu
Department of Mass Communication
Chukwuemeka Odumegwu Ojukwu University
Igbariam
grace4alfa@gmail.com
08036764024

\begin{abstract}
This paper examined the influence of the use of indigenous language and authority figures in the broadcast of COVID-19 messages among rural dwellers in South East Nigeria. This is against the backdrop of the failure of rural dwellers to pay attention and understand the COVID-19 pandemic messages which were disseminated in English language, and as such were not complying to the precautionary measures. The research was a descriptive survey. Five objectives guided the study which used the focus group discussion as the medium of data collection. The population was all rural dwellers in the five south-eastern states of Nigeria. The sample was 200 participants randomly selected from the five rural communities near the state capitals (Abakaliki-Nwofe; Awka- Achalla; Enugu- Ugwuaji; Owerri- Nworieubi and Umuahia). The Limited Effects theory formed the theoretical underpinning for the study. Data were analyzed through thematic transcription of the responses of the participants during the focus group discussion. Results obtained show that most rural dwellers do not have access to social media platforms. Also, rural dwellers get their information basically from markets, churches, and towns meetings. It was gathered that use of indigenous language and leaders of thought provided the needed understanding, reach and conviction of the rural dwellers on the reality of the COVID-19 pandemic. The study concludes therefore that the use of indigenous language and authority figures are useful in helping rural dwellers in the South East zone to understand and comply with the COVID-19 pandemic messages and precautionary measures. Sequel to the findings, the study recommends that the ministries of Information should adopt the use of opinion leaders in disseminating such vital information. Also there is need for all communities to translate vital and sensitive information in local dialects to enable easy understanding and compliance especially by rural dwellers.
\end{abstract}

Keywords: Authority figures; COVID-19; Indigenous language; Social media and Pandemic, 


\section{INTRODUCTION}

Towards the end of 2019, media all over the world's major news were awash with story of someone at the Huanan seafood market in Wuhan China who was infected with a virus from an animal. Experts suggested that the animal pangolin was the staging post for the virus before it spreads to humans. The high level of uncertainty that surrounds the origin of the COVID-19 virus and the animals/species that passed it on to man, has set scientists working to unravel the mystery as it will help in forestalling future ones. However, the Head of Department of Microbiology at Melbourne's Monash University, Professor Stephen Turner, opines that the virus is most likely to have originated from bats. Professor Edward Holmes of the University of Sydney, in a study in 2018, examined the likely origins of the virus using its genome. He avers that the species that served as intermediate host for the virus has not been identified.However, the Medical Journal, the Lancet on the analysis of the first 41 cases of COVID-19, found that 27 of them were directly exposed to the Wuhan market. This finding asserts that the known index case of COVID-19 was not exposed to the market which cast doubt on the existing story (CNN, Aljazeera, NTA).

In January 2020, China had provided huge public health interventions to contain the coronavirus outbreak. But by 18th of March 2020, mainland China outside Hubei province confirmed 13,415 cases of COVID-19 infection with 120 deaths. The rate at which the virus spread to other parts of the world put all nations on their toes as they took measures to contain it (CNN). The WHO declared the COVID-19 a pandemic as it was ravaging nations and their economies and almost bringing life on earth to a halt. By 13th February 2020, the virus had spread to 15 Asian countries with the first case of an African that lives in China who contracted the virus (CNN). The 21-year-old Cameroonian student Kem Senou Pavel Daryl who lives in Chinese city of Jingzhou, according to CNN, said he does not want to take the virus to Africa. He was treated in an isolation center where he showed signs of recovery in two weeks.

By February 27th, a first Nigerian case was confirmed by the Federal Ministry of Health. The press release informed that it was an Italian who works with Agip Saipen in Banana Island, Lagos. He came into Nigeria from Milan with symptoms and tested positive to the virus in the virology lab of Lagos University Teaching Hospital (LUTH) which is part of laboratory network of Nigerian Centre for Disease Control (NCDC).

With the spread of the virus alongside spread of information on the precautions to take and need to report suspected cases, it was apparent from media reports that many Nigerians were not convinced of this negative reality; also, there was urgent need to protect the people. All these prompted the president to issue a lockdown order on the Federal Capital Territory Abuja, Lagos and Ogun States while the NCDC, reportedly had to expedite action on contact tracing and provision of facilities that would help to contain and manage the pandemic. With this situation, states of the federation tried to adopt measures that would assist them in containing the pandemic. A veritable tool was found to be advocacy. The traditional media did not seem to be enough and because a lot of fake news had been spread through the social media including misinformation and disinformation, it became critical and necessary to spread the message of this pandemic to get to the masses. With the view expressed by Chen, Fay \& Wang (2011) that the rise of social media and online communities enhances access and sharing of information, it is then auspicious to find out the extent to which broadcasts, which are mainly in English language, have been able to convey the message of the deadly COVID-19. 
It was observed as reported in some media including ABS and NTA that many Nigerians especially rural dwellers do not care about the COVID-19 pandemic precautionary messages despite the numerous media campaign messages about the deadly pandemic. Could it be that many of them do not understand the COVID-19 messages being circulated across various media platforms; or could it be due to inaccessibility of media platforms especially in the rural areas or could this be due to the regard citizens have on the message medium and deliverers? Sequel to the above questions, in South East states, most communities had to translate the COVID-19 pandemic messages in their indigenous languages (dialects) to enable their people assimilate. Also, there was the need to use authority figures in these localities like the governors, traditional rulers, religious leaders, community heads, women's group leaders, and youths' representatives among others to educate rural dwellers about the pandemic. It is apparent that using these authority figures (who are held in high esteem by the rural dwellers) the people may have a rethink and may probably listen to the message on the premise that it may not be possible for their own sons and daughters to deceive them. It is against this background that the researchers examined how effective use of indigenous language and authority figures will be in disseminating COVID-19 pandemic messages in the South East states.

\section{STATEMENT OF THE PROBLEM}

With all the recommendations on how to stay free from the COVID-19 pandemic, it is not known to these researchers whether the people understand all the messages that are reeled out in the various media in English language. This erroneous belief may be the reason why many of them seem not to take any precautionary/safety measures against the COVID-19 pandemic. It is possible that this nonchalant attitude may have stemmed from their lack of understanding of English language (which is the principal means of disseminating the COVID-19 pandemic message).

Another possible reason may be the level of confidence reposed in the persons disseminating the COVID-19 messages. Some citizens have lost confidence in the authenticity of some messages in traditional and social media as a result of high rate of falsification or fake news. As a result, some may not pay attention to the COVD-19 pandemic message believing that it may also be false. These challenges create room for a search of better ways of enlightening citizens especially rural dwellers about COVID-19 pandemic. Now the problem of the study is to examine how effective the use of indigenous languages (dialect) and authority figures will be in helping rural dwellers in the South East understand COVID - 19 pandemic messages.

\section{OBJECTIVES OF THE STUDY}

This study seeks to establish the import of language and source in the spread of COVID-19 message. The specific objectives are:

$>$ ascertain the level of access/exposure to media platforms by rural dwellers in the South East zone.

$>$ find out the most popular media accessible to rural dwellers in the South East

$>$ x-ray factors that determine attitude of rural dwellers in the South East to the COVID19 pandemic messages being circulated

$>$ determine if the use of indigenous languages in dissemination COVID-19 messages helps understanding and compliance by rural dwellers in the South East.

$>$ ascertain the extent to which the use of authority figures in disseminating COVID-19 messages help understanding of and compliance to the message by rural dwellers in the South East. 


\section{RESEARCH QUESTIONS}

$>$ To what extent do citizens in South East rural areas have access to social media platforms?

$>$ Which media platform do residents mostly use to obtain information in rural areas in South East?

$>$ What factors influence attitude of residents of South East to the COVID-19 pandemic messages being circulated?

$>$ To what extent does the use of indigenous languages in disseminating COVID-19 pandemic messages help citizens understand the message?

$>$ How does the use of authority figures in disseminating COVID-19 pandemic message help citizens to understand and comply with the message?

\section{LITERATURE REVIEW}

\section{Indigenous Language}

As a major component of culture, language may be applied to improve various aspects of a person's life including health and economy. According to Gonzalez, Aaronson, Kellar, Walls \& Greenfield (2018), indigenous language fits into the broader umbrella of cultural values and activities. This may be why language revitalization efforts are gaining grounds across the globe in the forms of language immersion, primary education programme and adult language nests (Gunderson 2010).

Thorpe and Galassi (2014) on the project "Rediscovering Indigenous languages" make a case for the use of indigenous languages to enhance community engagement and collaborations. The power of indigenous language to enhance social cohesion cannot be overemphasized, especially in spreading vital information as in the case of COVID-19 which was announced a pandemic and threat to existence on planet earth. Today, the mass media broadcast messages mostly in English language but experts, including NTA have made a case for increased broadcast content in indigenous language. This may have informed the use of local languages in passing on some information in the media.

While Wilson and Ogri (2014) stress the need for mass media broadcast in indigenous language they have a highlight on the positive implication on National development. Some indigenous languages across the globe are reported to be on the verge of extinction while some have died. According to a recent United Nations record, 7000 indigenous languages are spoken around the world today and 4 out of every 10 of them are in danger of going extinct. (Kayla 2019). Kayla (2019) also reports that following this disclosure, countries of the world have started taking steps to ameliorate the situation while UN experts have called for a series of steps including new laws and international commitments to reverse what they describe as "historic destruction" of indigenous languages.

This fate according to Akinkurolere (2011) befalls Igbo language and other indigenous Nigerian languages today which may have informed their inclusion as complusory subjects in Nigerian Secondary Education curriculum. Nigeria's National Policy on Education as cited by Akinkurolere (2011) also encourages study of indigenous languages. In section 1 paragraph 8, it states that "the Federal Government beginning from late 1970s shall take official interest in and make policy pronouncements on the teaching of indigenous languages instead of concerning itself solely with English". Also in subsection 19(4), the document avers that "government should encourage the learning of indigenous languages". So far, one wonders the extent this policy has gone in promoting indigenous languages. It is however observed 
that some social factors like class and status inhibit the study and propagation of Igbo language as some parents prevent their children from speaking the language.However, when government has messages to disseminate to the masses, evidence shows it is better achieved using indigenous language. This is seen in public service messages in government media outfits.

\section{SOCIAL MEDIA AND COVID-19 INFORMATION DISSEMINATION}

The social media phenomenon is changed on the internet which affords the world all kinds of opportunities ranging from reading, watching to commerce. Kietzmann, Hermkens, McCarthy \& Silvestre (2011) aver that consumers of the Internet adopt social media handles and platforms to create, modify, share and even discuss content. There is documented evidence indicating the extent to which the world depends on social media to seek information and interact with others (Greenwood, 2016). Many workers all over the world apply social media to work which became more common during the COVID-19 pandemic era when the world almost got grounded and most work, education and communication were based on the social media as one of the ways to control the spread of the pandemic. While describing the social media as ubiquitous for social networking and content sharing, Asur and Huberman (2010) forecasted power of the social media to influence sentiment which became evident during the 2020 COVID-19 pandemic. The use of media in the Southeast Nigeria to disseminate information on COVID-19 was however common.

\section{COVID-19}

COVID-19 is an acronym formed by the WHO on the 11th day of February 2020 (Wu, 2020) for the novel Coronavirus disease that emerged in Wuhan City, Hubei province of China in December of 2019 which the WHO described as unprecedented and declared it a pandemic. Experts describe the COVID-19 as an infectious disease that is caused by severe/ acute respiratory syndrome driven by human-to-human transmission. There have been several speculations on the origin of the 2019 Coronavirus. Professor Perlman of University of Iowa contends that linking the origin to animals at the Wuhan market is coincidental though it cannot be ruled out even though he asserts that the possibility seems less likely because the genetic material of the virus had been found in the market environment. However, there is evidence that the so-called wet market where live animals are traded, had been connected to previous outbreaks of Corona viruses particularly SARS (Shereen, 2020) which an immunologist, Dr Michael Baker, upholds in the argument that people who were exposed to the Wuhan market were infected by the virus. By March 2020, COVID-19 has spread to all continents of the globe affecting 196 countries with four hundred thousand confirmed cases and over eighteen thousand deaths.

With the ravaging effects of the COVID-19 in parts of the world, the WHO came up with its research and development blueprint which was activated to accelerate diagnosis, vaccines and therapeutics for the novel Coronavirus (WHO, 2019). So far, there has not been a cure for this pandemic described as the enemy of mankind (Qian \& Ren, 2020). The authors suggest that in spite of the safety measures which the people should observe, the international community should develop better cooperation and strong solidarity in the joint efforts to fight against the spread of the pandemic.

\section{MANAGING COVID-19 PANDEMIC}

In Nigeria, managing the pandemic was a big challenge as it is critical that human behaviour and movement be controlled so as to curb the spread of the virus. Jelili (2020) avers that due to the cosmopolitan nature of Nigeria the country is prone to COVID-19 outbreak if stringent 
public health measures are not in place, citing the July 2014 case of a Liberian diplomat who entered Nigeria with Ebola virus disease through the Murtala Muhammed International Airport Lagos. However, the National Centre for Disease Control (NCDC) and the National Reference Laboratory Abuja geared up to face the challenges posed by COVID-19. Jelili (2020) informs that:

The NCDC has developed the Surveillance and Outbreak Response Management System (SORMAS) for case based reporting for epidemic prone diseases in eleven states of the federation. SirAware and Tatafo for event-based surveillance and incident management among NCDC staff members and Mobile Strengthening Epidemic Response System "mSers" for aggregate reporting. The establishment of National Incident Coordination Centre ICC for outbreak preparedness and response activities enables NCDC to gather intelligence reports daily identify impending public health threats and ensure that outbreak responses are wellcoordinated and controlled.

With the above initiatives put in place Nigeria seems to be in good position to respond but there is a pressing need to communicate the dangers of the disease to the masses especially at the grassroots where communication may be impeded due to many factors including language and limited effects. With identification of Nigeria's index case of covid-19 on the 28 of January 2020, the Federal Government took the proactive step of closing all airports and shutting down international travels among others and providing quarantine and isolation centres for COVID-19 patients. These efforts trickled down to the States.

In a world of social media which is fraught with all forms of misinformation and disinformation, fraudulent claims and fake news as well as politicization of the pandemic some people were not ready to heed the safety advice that will prevent the spread of the virus. The imminent dangers of poor circulation of information and education on the COVID-19 pandemic made groups, individuals and governments to devise means of delivering the information to the masses in the most efficient ways. The various arms of government and media have been applied to this cause. In the South East (where Igbo language is predominant) public service advertisement and messages were received on both traditional and new media. This confirms the position of the Nature Medicine (2020) that communication, collaboration and cooperation can stop the COVID-19, hence this effort to investigate the significant contribution of indigenous language to spreading and adoption of the COVID-19 message on social media.

\section{EMPIRICAL REVIEWS}

Wilson and Ogri (2014) examined the role of indigenous language broadcasting in national development. These scholars x-rayed a multilingual, pluralistic and multi-ethnic country with upwards of 500 indigenous languages where language should be a tool for National development through promotion of indigenous culture, national Identity, national pride and unity. On the contrary, the choice of English language as an official medium of communication in the mass media and society at large remains an inhibition to growth of indigenous languages. They therefore made a case for ways the mass media can activate national development by highlighting and promoting indigenous language. This study was a content analysis of some programs on the stations under review while interviews were used to gather qualitative data. The research found that media outfits have not harnessed the potential in adopting indigenous languages for national development. The study relates to the current one as both of them focus on the potential of indigenous language to achieve a greater national good through the media. However, while the study under review adopted content 
analysis and interview, the present study used FGD. Also, the study under review was in Calabar while this study is in South East Nigeria.

The research by Asur and Hubermann (2010) takes a look at the use of social media to strengthen languages with particular focus on endangered Sapmi languages in Europe. The study found that paucity of resources for teaching and promoting the language and the social media created the necessary ground for that. Apps and social media platforms and handles we are assorted to so as to augment but the researchers suggest avenues to strengthen endangered languages using the social media. This study relates to the current one in the sense that both have leaning to indigenous languages and social media. Also, the Sapmi language, though in Europe, is threatened likewise Igbo language which UNICEF noted is going into extinction. While the European scholars focused on learning and strengthening indigenous language using the social media, this work is on effectiveness of the use of indigenous language in spreading the COVID-19 message through social media.

\section{THEORETICAL FRAMEWORK}

The study will be supported by the Limited Effect theory by Paul Lazarsfeld (1940). The theory states that even if there is an effect created by the media on the thoughts and opinions of individuals; this effect is minimal or limited. The theory contends that messages pass from media through opinion leaders' opinion followers or social influences thus give rise to the two-step flow theory.

Opinion leader (June 2008) contends are individuals who are exposed to media content and spread the information and opinion provided by the mass media as far as they transmit them unchanged. However the consequences of direct effects on individuals who are not exposed to the media content give birth to the idea of "indirect effect". This theory has been linked to this study as information broadcast in indigenous language on social media passes through opinion leaders to opinion followers and have the tendency to be exposed to indirect effect.

\section{METHODOLOGY}

The study was a qualitative survey. The population for the study comprised of all residents in the states capitals of the five states that make up the South East geopolitical zone of Nigeria.The sample comprised 200 respondents selected from 5 communities in the 5 states. Forty (40) respondents were selected from each state to give a total of 200 respondents.Data were collected by means of focus group discussion (FGD) scheduled with 5 lead questions. Each of the 5 groups comprised of 6 persons made up of 3 males and 3 females and the discussions were held in the house of the President-General of the comunity. The researchers as journalists were permitted by law to move about to gather reports on the pandemic and monitor compliance to the lockdown rules in the selected communities. It was during the monitoring exercise that the research team conducted the interviews in form of focus group discussion (FGD). The responses of the discussants were recorded which were later transcribed thematically to answer the research questions.

\section{RESULTS}

Research Question One: To what extent do citizens in South - East rural areas have access to social media platforms?

The majority of the respondents were of the opinion that their access to social media platforms is poor. Only a few of the respondents (about 10\%) have access to Whats App 
According to one of the respondents, phone calls are limited to some areas due to poor network. Hardly do some residents in the area receive information via social media platforms. Most of the information the citizens receive are from newspapers, churches, news on TV and sometimes radio. In summary there is low access to social media by residents in rural communities in the South East. Some respondents however attest to the fact that some leaders in their communities who have access to social media information relay same to them. ]

Research Question Two: Which media platform do residents mostly use to obtain information in rural areas in Southeast?

The respondents agreed that most of the information they receive are from the church (for parishioners). Others said they hear most news from market, streets and town meetings. One of the respondents lamented that some of them that have TV and radio at home do not enjoy them because there is usually power outage. The situation is made worse because not many people can afford generator as alternative source of power in the villages.

In addition, some other discussants noted that a few of them get news through phones especially when there is network. However, some of the respondents agreed to the fact that poor network and irregular power supply limit the extent to which their phones could be helpful in accessing information. Based on the analysis, it could be deduced that the most popular source of information among rural dwellers in South East is local information sources like market, church, towns meeting and social gatherings as well as Authority figures or opinion leaders.

Research Question Three: What factors influenced attitude of residents of South East to the COVID-19 pandemic messages being circulated?

In response to this question, some respondents noted that there have been series of fake news flying around, so they felt the COVID-19 issues may just be one of such fables. Moreover, some other respondents added that they found it difficult to believe some news relating to how contagious the disease is without remedy; especially when they do not know the person circulating the information. This, of course is traceable to a lot of deceptions that have been witnessed by many citizens in the community. Many people have been duped, killed or maltreated due to compliance to some fake news in circulation. At the end of the day, it was discovered that the sources of such news are not identifiable or authentic. According to one of the discussants, it may be very difficult for some people to believe any news circulating except they are sure of the source and the personality disseminating the news.

Another respondent quickly added that there was an instance where some people have been beaten up for spreading news which was believed to be fake. It was an unfortunate event. As a result, many of us here do not care to listen to most news especially if it has not come from a credible known source like radio or TV; more so, we don't even see light always, the man concluded. It then means that majority of the residents do not botherabout COVID-19 news because of fear of being fake and the issue of authenticity of the disseminators.

Research Question Four: To what extent does the use of indigenous language and dialects in disseminating COVID-19 pandemic messages help citizens understand the message?

From the discussion held, many discussants testified that all the time the news of COVID-19 pandemic flew around, they never understood anything. The major reason was because many of the rural residents are not conversant with English language which was the principal means of dissemination.The few respondents who said they are privileged to listen to radio and television news complained that they hardly get the gist very well. 
To make the matter worse, most of the times, there will be power outage so, one may not even be opportuned to hear the news. One of the respondents noted that it was only when their community heads held meeting and they translated the COVID-19 message in their local dialect that some of them knew what was happening. In the respondent's exact words he said "we were going about our normal business not minding all the rumor flying around about COVID-19 ... Later the chiefs in our town held a meeting, thereafter our community head instructed our town crier to go round the villages and announce the COVID-19, pandemic messages, its mode of operation, symptoms, mode of spread and preventive measures in our local dialect. Before then, one University don from my village (who is an expert in linguistics) was consulted at Awka to translate the COVID-19 message from English language to our local tongue. It was after the town crier went round that many residents began to understand and appreciate the message. The respondents noted that though many rural dwellers do not have phones that are WhatsApp compliant, their relatives, who have, helped in spreading those messages to them.

Notable among the messages mentioned by respondents are: the one produced by the traditional ruler of Okija and shared to members of the community; the one produced by a prominent Anam indigene in Anam dialect as well as those produced in Orumba and Nnewi dialects, all in Anambra state. Others mentioned are production in Nkanu and Nsukka dialects of Enugu state; the 5- dialect production for radio and television in Ebonyi state; the various productions by Mbaise clan of Imo state and the production voiced by the Governor of Abia state, OkezieIkpeazu in local dialect.

One of the discussants even said that if they had not used our local dialect to spread the news may be people in our village will die too much because nobody cared to listen to news and radio all these while. In essence, the use of indigenous language helped residents to understand the COVID-19 pandemic message very well and to abide by the safety measures.

Research Question Five: How does the use of authority figures in disseminating COVID-19 pandemic message help citizens to understand and comply with the message?

Authority figures refer to personalities or entities that the people have respect and regard for. Examples are Pastors, Parish Priests, Reverend Fathers, Traditional rulers, village heads, community leaders etc. These people have voices among their subjects and as such can command great influence.

In responding to this question, some respondents noted that in their communities, there are people that when they talk, others will listen and there are others when they talk, nobody cares. One respondent stated that in their community, their Parish Priest took time (during one Sunday service) to explain to them (in their dialect) how to stay safe in the COVID-19 era. The Priest even gave few minutes for people to ask questions, she added. Another discussant told the group that their traditional ruler summoned everybody to the village square and explained to them why they must stay at home and take other precautionary measures against COVID-19. "The Igwe even told us that he (the Igwe) cannot be deceiving his own people, so he had to explain to us why we must obey the lockdown order, stating that it is for our good".

Another discussant added that "'if not that our Reverend Father said so, me, I would not have listened to these their rumours; but after Father talked that Sunday, my mind was convinced that it is true"'.Going by the responses of the discussants, it could be seen that using authorit 
figures like traditional rulers, village heads, Parish Priests, Reverend Fathers etc was very useful and helpful in making the residents understand the COVID-19 pandemicmessage and to adopt the measures.

A lot of times, most people trust and respect these authority figures especially when they are indigenes. The people believe that their own sons and daughters cannot come to deceive their own people. If they do, they will always come home to face the consequences and possibly, sanctions. It could then be concluded that the use of authority figures in disseminating COVID-19 pandemic messages helped residents to understand, adopt and comply with the COVID-19 pandemic safety rules.

\section{CONCLUSION}

The study was on the influence of the use of indigenous language and authority figures in disseminating COVID-19 pandemic messages among rural dwellers in South East Nigeria.

From the study, it was gathered that rural residents have poor access to social media platforms hence they hardly access news via social media. In the same vein, it was gathered that many rural residents in South East get news majorly from local sources like markets, churches or town meetings. Many residents seem to neglect the COVID-19 pandemic messages in circulation because of distrust about their truthfulness and authenticity of their sources.The study found out that the use of local dialect (indigenous language) was very effective in helping rural residents in South East to understand the COVID-19 pandemic messages. Finally the use of authority figures helped residents to understand, adopt and comply with the COVID-19 pandemic safety and precautionary rules.

\section{RECOMMENDATIONS}

Based on the findings from the study, the following are recommended:

$>$ There is need to provide electricity and social media platforms for rural dwellers to enable them access news and information faster and better.

$>$ Most rural dwellers lack media platforms for accessing information hence it is instructive for the government to extend communication network, and TV stations in rural areas to help them obtain first hand information.

$>$ There is need for the Ministry of Information to monitor the authenticity of any information or news being disseminated to boost the confidence of the populace.

$>$ The study found that the use of local dialect helped residents to understand the COVID - 19 pandemic message, hence it is imperative that all communities in Nigeria translate the COVID-19 message in their indigenous dialects to help rural dwellers understand, adopt and to comply with the safety rules.

$>$ The government should sustain use of authority figures in the dissemination of important messages to the masses since the masses trust them and have more regard for them.

\section{REFERENCES}

Akinkurolere, S.O. (2011). Revisiting the National Policy on Education on the need for introducing bilingual medium of instruction in Nigerian schools. Ondo Journal of Arts and Social Sciences (OJASS) X (1):1- 9.

Asur, S. \&Hubermann, B.A. (2010). Predicting the future with social media.IEEE/WIC/ACM.International Conference on Web Intelligence and Intelligent Agent Technology. 1: 492 - 499. 
Chen, Y.; Fay, S. \& Wang, Q. (2011). The role of marketing in social media: How online consumer reviews evolve. Journal of Interactive Marketing, 25 (2): 85 - 94.

Editorial of Nature Medicine (2020). Communication, collaboration and cooperation can stop the 2019 corona virus. Retrieved from www.nature.com/naturemedicine.

Gonzalez, M.B.; Aaronson, B.D.; Kellar, S.; Walls, M. \& Greenfield, B.L. (2018).Language as a facilitator of cultural connection.Ab-Original: Journal of Indigenous Studies and First Nations' and First Peoples' Culture. AbOrig 1(2): 176-194.

Greenwood, S.; Perrin, A.\& Duggan, M. (2016). Social media update 2016. Pew Research Centre. 11(2): 1 - 10.

Gunderson, D.(2010). White earth nation makes ojibwe its official language. Retrieved from>https//blogs.mprnews.org/statewide/2010/08/white_earth_makes_ojibwe_official _language.

Holmes, E.C.; Rambaut, A. \& Anderson, K.G. (2018). Pandemics: Spend on Surveillance not Prediction. Journal of Nature. 558 (7709): 180 - 182.

Kietzmann, J.H.; Hermkens, C.; McCarthy, I.P. \& Silvestre, B.S. (2011).Social media? Get serious! Understanding the functional building blocks of social media.Business Horizons. 54 (3): 241 - 251.

Long, K; Wu, J.T.; Liu, D, \& Leung, G.M. (2020). First- wave COVID-19 transmissibility and severity in China outside after control measures, and second wave scenario planning: a modeling impact assessment. The Lancet April 8. https://doi.org/10.1016/s0140-6736(20)30747-7.

McQuail, D. (2005). Mass communication theory. (5th ed.). London: Sage.

Nigeria Centre for Disease Control (NCDC) (2020).Public health advisory to Nigerians on novel corona virus.Availablle at: http://ncdc.gov.ng/news/222/3rd-february-2020\%7cpublic-health-advisory-nigerians-on-novel-coronavirus-\%28\%233\%29.

Qian, X. \&Ren, R. (2020).Fighting against the common enemy of COVID-19: a practice of building a community with a shared future for mankind.Infectious diseases of poverty. April \#9 article \# 34: 265 - 269.

Shereen, M., A. (2020). COVID-19 infection: Origin, transmission and characteristics of human Corona viruses. Journal of Advanced Research24:91-98. Retrieved from: https://doi.org/10.1016/j.jare.2020.03.005.

Thorpe, K. \&Galassi, M. (2014). Rediscovering indigenous languages: the role and impact of libraries and archives in cultural revitalization. Australian Academic and Research Libraries. 45 (2): 81 - 100.

Turner, S.; Collas, P. \& Bell, T. (01/01/20 - 31/12/23). The T-cell genome in 3D: understanding chromatin dynamics during $\mathrm{T}$-cell responses to virus infection. 
Volume 1 Number 2

Wilson, D. \&Ogri, E.U. (2014).Mass media, indigenous languages, broadcasting and national development. A study of selected broadcasting stations in Calabar. The Nigerian Journal of Communication (TNJC) 14 (1): 79 - 102.

Wu, Y.; Chen, C. \&Chan, Y. (2020). The outbreak of COVID-19: An overview. Journal of the Chinese Medical Association 83 (3):217-220. 